KRZYSZTOF JAGUSIAK

UNIWERSYTET ŁÓDZKI / UNIVERSITY OF LODZ

iD https://orcid.org/0000-0003-3751-7882

Jolanta Dybąa

UniWERSYTET Łódzki / University of LODZ

iD https://orcid.org/0000-0002-5635-5834

Maciej KokoszKo

Uniwersytet ŁódzKi / UNIVERSiTy OF LODZ

iD https://orcid.org/0000-0002-9563-2902

\title{
Historiae Grzegorza z Tours jako źródło informacji o diecie mieszkańców VI-wiecznej Galii
}

Abstract

\section{Historiae of Gregory of Tours as a source of information on the diet in $6^{\text {th }}$-century Gaul}

$T$ he present article focuses on the presentation of excerpts from the main his1 torical work written by Gregory, bishop of Tours, which deal with food and drink in the diet of his contemporaries in Gaul. The author devoted most space to the menu of the Frankish state elite - royal families, bishops and secular nobles. In addition, he gave some information on a diet of people who avoided the luxury and pleasures for God.

The narration of Gregory is our article supported in our article by other sources: medical, historiographical, gastronomical, patristic etc. The most important among them were these written by Venantius Fortunatus, Sidonius Apollinaris, Anthimus, Galen, Oribasius, and Athenaeus of Naucratis.

The analysis of the sources, leads us to the conclusion that despite the deep, multidimensional changes that took place between the $5^{\text {th }}$ and $6^{\text {th }}$ centuries in the areas known as Gaul, there were no major changes in the nutritional habits of the local people. It does not mean that the Germanic population did not influence the culinary world of $6^{\text {th }}$-century Gaul in any way. Sources confirm such influence, however, on this field it was not great. On the basis of the preserved 
treatises - and the Historiae of Gregory of Tours is one of our key source - one can observe the survival (and continuation) of ancient culinary traditions in the Frankish state.

Keywords: history, history of food, Gregory of Tours, Gaul

Streszczenie

\begin{abstract}
A rtykuł skupia się na przedstawieniu fragmentów głównego dzieła historyczneA go napisanego przez Grzegorza, biskupa Tours, w których mowa jest o pożywieniu i napojach w diecie współczesnych mu mieszkańców Galii. Autor poświęcił najwięcej miejsca jadłospisowi elity państwa Franków: rodzin królewskich, biskupów i świeckich możnych. Prócz tego podał garść informacji o tym, czym żywili się ludzie stroniący w imię poświęcenia dla Boga od uciech stołu. Dieta pozostałych ludzi interesowała go tylko, gdy dotyczyło to skrajnych zachowań w obliczu klęski głodu.

Przekaz zawarty w Historiae został przez nas ukazany na tle fragmentów innych źródeł $z$ epoki późnego antyku i wczesnego średniowiecza, które przybliżaja gastronomiczne realia tamtych czasów i stanowią odniesienie dla wiadomości podanych przez Grzegorza z Tours. Duże znaczenie miał tu korpus pism medycznych autorstwa Galena, Orybazjusza, Aecjusza oraz szczególnie bliskiego geograficznie i czasowo Grzegorzowi Antimusa. Ważne były też pisma Sydoniusza Apolinarego i Wenancjusza Fortunata. Pozostałe źródła (patrystyczne, kulinarne, historiograficzne etc.) miały dla nas mniejsze znaczenie, choć uzupełniały rekonstruowana w artykule rzeczywistość.

$\mathrm{Na}$ podstawie analizy wykorzystanych dzieł można wysnuć wniosek, że mimo głębokich, wielowymiarowych przemian, jakie nastapiły między V a VI stuleciem na terenach określanych jako Galia, w wyżywieniu zamieszkujących je ludzi nie zaszły większe zmiany. Zasób produktów (zarówno tych, dostępnych elitom, jak i reszcie społeczeństwa), uzyskiwanych $z$ nich potraw i zwyczajów żywieniowych pozostał bardzo zbliżony. Nie oznacza to, że ludność germańska nie wpłynęła w żaden sposób na kulturę żywieniową VI-wiecznej Galii. Źródła potwierdzają ślady takiego wpływu, jednak w tej dziedzinie życia nie był on wielki. Na podstawie zachowanych traktatów - a Historiae Grzegorza $z$ Tours sa jednym $z$ kluczowych świadectw tego zjawiska - można więc mówić o przetrwaniu (i dalszym trwaniu) późnoantycznych tradycji kulinarnych w państwie Franków.
\end{abstract}

Słowa kluczowe: historia, historia jedzenia, Grzegorz z Tours, Galia

ytułem wstępu do właściwych rozważań warto zwięźle przed-
stawić sylwetkę autora głównego, analizowanego przez nas
w artykule, źródła. Urodził się w 538 lub 539 r. w okoli-
cach Clermont ${ }^{1}$. Pochodził ze znamienitej galijskiej rodziny arysto-

1 Szczegóły na temat biografii Grzegorza z Tours por. H. Leclercq, Grégoire de Tours, [w:] Dictionnaire d'archéologie chrétienne et de liturgie, t. VI, p. 2, 
kratycznej. Większość jego poprzedników na urzędzie biskupim w Tours, których wymienił na końcu swoich Historiae, była z nim w jakiś sposób spokrewniona ${ }^{2}$. W okolicach roku 563 został diakonem. Zaczął wówczas przebywać w rodzinnym majątku, którym osobiście zarządzał. Gdy w 563 r. bardzo ciężko zachorował, udał się $z$ pielgrzymka do grobu św. Marcina w Tours i tam odzyskał zdrowie. W 573 r., wkrótce po wyświęceniu na prezbitera, został biskupem Tours.

Urząd, jeden $z$ najważniejszych $\mathrm{w}$ hierarchii kościelnej państwa Franków, sprawował aż do śmierci około 594 r. $Z$ racji swego stanowiska był w ciagu około 20 lat posługi biskupiej nierzadko w centrum politycznych wydarzeń królestwa znajdującego się w burzliwym stadium swego istnienia.

Dzieło biskupa Grzegorza, które jest przedmiotem naszej analizy (w artykule posługiwać się będziemy tytułem Historiae, choć w Polsce znane jest głównie jako Historia Franków), jest najważniejszym utworem w jego spuściźnie ${ }^{3}$. Do naszych czasów praca ta przetrwała w łacznie 50 manuskryptach zawierajacych jej całość bądź większe lub mniejsze fragmenty. Długo panował pogląd uznajacy Historiae za dzieło historiograficzne, dlatego też tak je czytano, rozumiano i interpretowano. W związku $z$ tym samego autora postrzegano jako osobę naiwna, przesadna i prymitywna w swoich poglądach. Ostatnio podejście to uległo zmianie i badacze uważaja, że Historiae nie sa kronika, bardziej praca historiozoficzna, mająca na celu pouczenie czytelników, a nie zaznajomienie ich z przeszłością ${ }^{4}$. Cztery pierwsze księgi opisują dzieje od początku

Paris 1925, k. 1711-1753; E. James, Introduction, [w:] Gregory of Tours, Life of the Fathers, trans. E. James, Liverpool 1991, Translated Texts for Historians, 1, s. IX-XII; I. W o od, Gregory of Tours, Bangor 1994; D.A. Sikors ki, Wstęp, [w:] Grzegorz z Tours, Historie. Historia Franków, przekł. K. Liman, T. Richter, Kraków 2002, s. 7-44; M. Heinzelman n, Gregory of Tours. History and Society in the Sixth Century, trans. Ch. Carroll, Cambridge-New York 2006, s. 7-35; id e m, Gregory of Tours. The Elements of a Biography, [w:] A Companion to Gregory of Tours, ed. A.C. Murray, Boston 2015, s. 5-34.

${ }^{2}$ M. Heinzelmann, Gregory of Tours. History..., s. 23-28.

${ }^{3} \mathrm{Na}$ temat Historiae autorstwa Grzegorza por. W. Goffart, The Narrators of Barbarian History (A.D. 550-800). Jordanes, Gregory of Tours, Bede and Paul the Deacon, Princeton 1988, s. 112-127; D.A. Sikorski, op. cit., s. 16-40; M. Heinzelmann, Gregory of Tours. History..., s. 94-152; A.C. Murray, The Composition of the Histories of Gregory of Tours and Its Bearing on the Political Narrative, [w:] A Companion to..., s. 61-101.

${ }^{4}$ D.A. Sikorski, op. cit., s. 34-35. 
świata do 575 r., następne zaś czasy współczesne autorowi i to na nich właśnie zamierzamy się skoncentrować.

Historiae Grzegorza obfituja we wzmianki odnoszące się do pokarmów i napojów, a także do czynności jedzenia i picia, czy szerzej kultury kulinarnej współczesnych mu mieszkańców Galii. Nimi chcemy się zająć w dalszej części naszego tekstu. Rozsiane są one w wielu miejscach dzieła i maja różny charakter. Różni je przede wszystkim długość i stopień szczegółowości oraz znaczenie dla opowiadanych zdarzeń, niekiedy bowiem stanowia jedynie krótkie napomknięcia w toku poświęconej czemu innemu narracji, innym zaś razem przedstawiają istotna przyczynę bądź sedno opisywanych w danym passusie historii.

Wzmianki te związane sa bezpośrednio lub pośrednio $z$ agronomią (zatem opowiadaja też o klęskach żywiołowych, głodzie, nieurodzaju, niezwykłych zjawiskach i pustoszeniu zasiewów przez ludzi), zwyczajami kulinarnymi czy też $z$ przekraczaniem przyjętych w związku $z$ konsumpcja norm (zarówno rozpusta, jak i wstrzemięźliwością).

Produktem spożywczym, który na stronach Historiae pojawia się najczęściej, jest wino. Grzegorz wzmiankuje je przy różnych okazjach. Uwagę zwraca powszechność jego picia wśród pojawiających się w narracji biskupa Tours osób czy zbiorowości. Część informacji dotyczacych wina stanowia u niego krótkie, czasem rzucane jakby mimochodem uwagi, w których pisze np., że trafiało ono na stoły podczas królewskich uczt u Burgundów ${ }^{5}$ albo że było obecne na stole frankijskiego króla Chilperyka ${ }^{6}$. Wprawdzie wzbogacaja one i ożywiaja narrację, same w sobie nie sa jednak szczególnie wartościowe, fakt bowiem konsumpcji wina przez elity wpierw celtyckich, a potem germańskich plemion ulegających czarowi tego trunku, a także innych aspektów cywilizacji grecko-rzymskiej jest dobrze znany ${ }^{7}$. Ciekawiej brzmia passusy dotyczące rozmiarów

${ }^{5}$ Gregorii Turonensis Libri historiarum X, III, 5, eds B. Krusch, W. Levinson, Hannover 1884 [dalej: Grzegorz z Tours, Historiae].

${ }^{6}$ Grzegorz z Tours, Historiae, V, 18.

$7 \mathrm{~W}$ interesujacym nas okresie wino było już dobrze zadomowione na stołach Franków (a przynajmniej tych lepiej sytuowanych spośród nich) i jego picie stanowiło pewną normę, choć równolegle istniał popyt na piwo i miód pitny, por. np. Venanti Fortunati carmina, XI, 4, [w:] Venanti Honori Clementiani Fortunati presbyteri italici opera pedestria, rec. F. Leo, Berolini 1881 [dalej: We nancjus z Fortunat, Carmina]; Venanti Fortunati vitae sancte Redegundis, XV, 36, [w:] Venanti 
handlu winem, jak ten o kupcu Krzysztofie i jego wyprawie do Orleanu, gdzie zgromadzono olbrzymia ilość rzeczonego trunku ${ }^{8}$, czy o pojemnych magazynach, w których frankijscy królowie i możni przechowywali znaczne jego zapasy ${ }^{9}$, choć przecież zarówno kupczenie winem, jak i jego magazynowanie w kraju takim, jak VI-wieczna Galia nie powinno wywoływać zdziwienia.

Grzegorzowi zdarzało się jednak zapisywać informacje, które znacznie więcej mówią o kulturze picia wina w jego czasach i których czasami nie sposób znaleźć w innych źródłach $z$ epoki. O mieszkańcach Dijon stwierdził, że mają wokół miasta winnice dające tak pyszne wino, że gardza nawet szalońskim ${ }^{10}$. Ta krótka wzmianka sugeruje, że trunek pochodzący $z$ okolic Chalon-sur-Saône był w czasach Grzegorza wysoko ceniony nie tylko na rynku lokalnym, lecz także zapewne w całej Galii (odległość dzieląca Tours od Chalon-sur-Saône wydaje się, jak na warunki wczesnośredniowieczne, zbyt duża, by mówić jedynie o regionalnej sławie tego wina). Co więcej, opinia głosząca, że wino dijońskie może być jeszcze lepsze, kusząco koreluje $z$ późniejszą sławą win burgundzkich, cierpliwie wytwarzanych przez średniowiecznych mnichów ${ }^{11}$.

Honori Clementiani Fortunati presbyteri italici opera pedestria, rec. B. Krusch, Berolini 1885. O importowaniu wina przez Germanów mieszkających na prawym brzegu Renu pisał już Tacyt (P. Cornelius Tacitus, Germania. Publiusz Korneliusz Tacyt, Germania, 23, 1, przekł. T. Płóciennik, Poznań 2008). Około 150 lat wcześniej Cezar pisał o belgijskich Nerwiach, którzy nie importują wina, co m.in. odróżnia ich od mieszkających bardziej na południe, utrzymujacych ze światem rzymskim wymianę handlową (a zatem pijących wino) Galów (C. Iuli Commentarii Rerum in Gallia Gestarum VII A. Hirti Commentarius VII, I, 1, 3, ed. T. Rice Holmes, Oxonii 1914). Znajomość tego trunku na interesującym nas obszarze Galii i wśród ludów germańskich z Galią sąsiadujacych miała więc w czasach Grzegorza już kilkusetletnią historię.

${ }^{8}$ Grzegorz z Tours, Historiae, VII, 46. Sednem tej opowieści nie jest jednak handel winem, a ponura śmierć Krzysztofa $z$ rąk własnych sług, niezadowolonych $z$ powodu błahej przyczyny.

${ }^{9}$ Grzegorz z Tours, Historiae, VII, 15; VII, 22. Takie magazyny bywały niekiedy, wedle słów Grzegorza, rozkradane w przypadku śmierci monarchy bądź politycznego upadku możnowładcy.

10 Grzegorz z Tours, Historiae, III, 19.

${ }_{11}$ A. Dominé, E. Supp, U. Sautter, W. Faß bender, Burgundia, [w:] Wino, ed. A. Dominé, przekł. Z. Zawadzki, Ożarów Mazowiecki 2008, s. 180-209. Literackim świadectwem głębokich korzeni produkcji wina charakteryzującego się wysoka jakością w rejonie późniejszej Burgundii jest słynny fragment panegiryku skierowanego przez mieszkańców Autun do cesarza Konstantyna w 312 r., w którym mowa o trunkach produkowanych w tej krainie. Por. T. Unwin, Wine and 
Opisując podstępna próbę zamordowania frankijskiego dostojnika Eberulfa, który oskarżony o udział w zamachu na króla znalazł azyl w kościele św. Marcina w Tours, Grzegorz stwierdza, jak to niejaki Klaudiusz, podjawszy się dokonania tej zbrodni, postanowił udawać przed swą ofiara przyjaciela. Zbliżył się do niego, a pewnego razu, gdy już obaj zanadto popili, spytał Eberulfa, czy nie ma on $\mathrm{u}$ siebie wina przyprawionego na słodko, albo choć jakiegoś mocniejszego niż pite dotąd. Aby uczynić zadość prośbie fałszywego przyjaciela, Frank posłał swoje sługi po napitek pochodzacy $z$ Laodycei i Gazy znajdujacy się w jego zapasach ${ }^{12}$. Widzimy tu nie tylko żywa praktykę doprawiania wina w celu zmiany jego właściwości smakowych, dobrze znana od czasów antycznych i poświadczoną szczególnie wyraźnie u autorów dzieł medycznych, jak Dioskorides czy Orybazjusz (którzy wymieniają szereg przypraw stosowanych w tym celu, np. piołun, hyzop, płatki kwiatów, miód, żywice sosnowa) $)^{13}$, lecz także - skądinąd nieodosobnione - świadectwo obecności w VI-wiecznej Galii win importowanych niekiedy $z$ odległych rejonów Morza Śródziemnego. Zwłaszcza wino pochodzace $z$ okolic Gazy stało się na Zachodzie w V i VI w. synonimem trunku doskonałej jakości - pojawiając się m.in. na kartach dzieła Sydoniusza Apolinarego ${ }^{14}$ - co wiązało się $z$ rozwojem tamtejszego rolnictwa (w tym winogrodnictwa), którego początek datuje się na IV w. i wiąże $z$ rozkwitem monastycyzmu ${ }^{15}$. Sydoniusz poza

the vine: An historical geography of viticulture and the wine trade, London-New York 2005, s. 116-117; D. Thurmond, From vines to wines in classical Rome. A handbook of viticulture and oenology in Rome and the Roman West, Leiden-Boston 2017 , s. 43-45.

12 Grzegorz z Tours, Historiae, VII, 29.

$13 \mathrm{Na}$ temat różnych dodatków do win stosowanych w czasach grecko-rzymskich i później por. np. Pedanii Dioscuridis Anazarbei de materia medica libri V, V, 6,$5 ; \mathrm{V}, 27,1,1 ; \mathrm{V}, 34,1,1-2,5 ; \mathrm{V}, 39,1,1 ; \mathrm{V}, 40,1,1-2$, 4, ed. M. Wellmann, vol. I-III, Berolini 1906-1914; Oribasii collectionum medicarum reliquiae, V, 25, 10, 1-14, 1; V, 25, 35, 2-38, 2; V, 25, 39, 2; V, 33, 1, 1-5, 4, ed. I. Raeder, vol. I-IV, Lipsiae-Berolini 1928-1933 [dalej: Orybazjusz, Collectiones medicae]; Anthimus, De observatio ciborum, 15, ed. S.H. Weber, Leiden 1924 [dalej: Antimus, De observatione ciborum]; Aetii Amideni libri medicinales I-VIII, III, 73, 1-8, ed. A. Olivieri, Lipsiae-Berolini 1935-1950 [dalej: Aecjusz z A midy, Iatricorum libri].

${ }^{14}$ Por. C. Sollii Apollinaris Sidonii carmina, XVII, 386, [w:] Patrologiae cursus completus, series latina, ed. J.-P. Migne, vol. LVIII, Paris 1862 [dalej: Syd onius z A polinary, Carmina].

${ }_{15}$ P. Mayerson, The wine and vineyards of Gaza in the Byzantine period, „Bulletin of the American Schools of Oriental Research” 1985, No. 257, s. 75-80. Popularność wina $z$ Gazy na zachodzie Europy autor przypisuje ruchowi piel- 
falernem wspomina jeszcze trunek $z$ Chios ${ }^{16}$, a kolejny autor, współczesny Grzegorzowi Wenancjusz Fortunat, pisze przy innej okazji o słynnym winie $z$ Falernum, podanym do posiłku u pewnego galijskiego biskupa ${ }^{17}$, poświadczając tym samym kolejny kierunek importu do Galii. Wspomniana zaś praktykę doprawiania wina do smaku przywołuje Grzegorz przy jeszcze jednej okazji. W rzeczonym trunku dosłodzonym miodem i doprawionym piołunem (co wedle biskupa Tours było normalnym zwyczajem) królowa Fredegunda rozpuściła truciznę, by pozbyć się jednego ze swych oponentów ${ }^{18}$. W Historiae czytamy o jeszcze jednej praktyce związanej z piciem wina, mianowicie podgrzewaniu go. Takim ciepłym napitkiem raczyli się strażnicy pilnujący na rozkaz biskupa Kautyna z Clermont jednego $z$ jego nieposłusznych kapłanów ${ }^{19}$.

Jednak najwięcej miejsca przy okazji pisania o winie poświęcił Grzegorz ekscesom związanym $z$ jego nadmiernym spożyciem oraz skutkom incydentalnych pijaństw i stałego nadużywania alkoholu. Nie ma potrzeby przytaczać tu wszystkich tego rodzaju opisów, posłużymy się więc jedynie przykładami ilustrującymi pewne zachowania. I tak nadmierne picie wina czyni ludzi niezdolnymi do obrony przed wrogami, którzy niekiedy tylko czyhaja na taka okazję, i może skończyć się dla upojonego tragicznie. Tak zdarzyło się w przypadku Lupusa i jego świty, spalonych żywcem we własnym dworze przez Ursusa ${ }^{20}$. Upici winem ludzie nie kontroluja się i nie panuja nad soba, przez co bywaja porywczy i krzywdzą innych, jak wspomniany Eberulf, który po pijanemu skatował sługę niemal na śmierć ${ }^{21}$. Pijani ludzie również sami na siebie ściągają nieszczęście, jak diakon Teodulf, który, zamroczony winem, stracił równowage i zabił się, spadając $z$ murów miejskich Angers ${ }^{22}$. Co gorsza, nadużywanie wina powoduje poważne choroby. Biskup Euniusz z tego,

grzymkowemu, argumentując, że powracajacy w rodzinne strony z Palestyny pobożni wędrowcy musieli opowiadać już na miejscu o jakości tego trunku, co wzbudzało ciekawość ich pobratymców i przyczyniało się do importu.

16 Sydoniusz Apolinary, Carmina, XVII, 386. Autor zarówno w przypadku wina z Gazy, Falernum, jak i Chios pisze przewrotnie, że gość na organizowanym u niego przyjęciu nie będzie mógł liczyć na tego typu specjalne trunki, bo wszystko będzie skromne.

${ }_{17}$ Wenancjusz Fortunat, Carmina, III, 13 c.

18 Grzegorz z Tours, Historiae, VIII, 31.

19 Grzegorz z Tours, Historiae, IV, 12.

${ }^{20}$ Grzegorz z Tours, Historiae, IV, 46.

${ }^{21}$ Grzegorz z Tours, Historiae, VII, 22.

${ }^{22}$ Grzegorz z Tours, Historiae, X, 14. 
wedle Grzegorza, powodu doznał krwotoku $z$ ust i nosa ${ }^{23}$, a wspomniany już biskup Kautyn - zachorował na epilepsję ${ }^{24}$. Ulec nałogowi mogą niepostrzeżenie nawet ci, którzy wybrali życie w ascezie, jak pewien Winnoch, który ostatecznie zmarł niemal pograżony w obłędzie po tym, jak poddał się nałogowi i stał się niebezpieczny dla otoczenia ${ }^{25}$. Wreszcie nadużywanie wina odróżnia fałszywych proroków od prawdziwie świątobliwych mężów, co ilustruje przykład pewnego oszusta udającego człowieka pobożnego, złapanego w końcu nieprzytomnego $z$ przepicia ${ }^{26}$. Opisy te jakby mimochodem, choć zapewne to celowy zabieg autora, przekonuja czytelnika, że pijaństwo jest złe, niemoralne i przynosi wiele nieszczęść ${ }^{27}$.

Jednak picie wina, które $\mathrm{z}$ obrazu świata przedstawionego w $\mathrm{Hi}$ storiae jawi się jako coś powszechnego, samo w sobie nie jest naganne i nie zostało przedstawione przez Grzegorza w złym świetle. Nie powinno to zresztą dziwić nie tylko $z$ racji ówczesnych galijskich zwyczajów kulinarnych (co dobrze ilustruja wzmianki w utworach przyjaciela Grzegorza, Wenancjusza Fortunata ${ }^{28}$, czy wcześniejsze Sydoniusza Apolinarego ${ }^{29}$ ), ale przede wszystkim rygorów religii chrześcijańskiej, nie tylko niewzbraniającej spożywania tego trunku ${ }^{30}$, lecz także wykorzystującej go w liturgii. Taki stosunek do wina dobrze ilustruje wzmianka o pokucie, jaka decyzją synodu w Mâcon (585 r.) miał odbyć za zdradę króla Guntrama

${ }^{23}$ Grzegorz z Tours, Historiae, V, 40.

${ }^{24}$ Grzegorz z Tours, Historiae, IV, 12.

${ }^{25}$ Grzegorz $z$ Tours, Historiae, VIII, 34.

${ }^{26}$ Grzegorz $z$ Tours, Historiae, IX, 6.

27 Nieco wcześniej surowo na temat nadużywania alkoholu wypowiadał się inny galijski biskup, Cezary z Arles, którego pisma miały znaczny wpływ na Kościół w Galii i, zapewne pośrednio, na samego Grzegorza z Tours. Por. L. Bailey, "These Are Not Men": Sex and Drink in the Sermons of Caesarius of Arles, „Journal of Early Christian Studies" 2007, vol. XV, No. 1, s. 23-43.

${ }^{28}$ Por. Wenancjusz Fortunat, Carmina, III, 27; VII, 2.

29 Por. C. Sollii Apollinaris Sidonii epistulae, VIII, 11, 235, [w:] Patrologiae cursus completus, series latina, ed. J.-P. Migne, vol. LVIII, Paris 1862.

30 Chodzi oczywiście o picie wina, a nie upijanie się nim czy nadużywanie go, które były przez Kościół oficjalnie potępiane, a zarazem stanowiły pojawiający się niekiedy problem. To wyraźne rozróżnienie dobrze widać np. u Palladiusza, Grzegorza z Nyssy czy Jana Chryzostoma. Jeśli chodzi o czasy bliższe Grzegorzowi $z$ Tours, to warto wspomnieć o regule Benedykta $z$ Nursji, który przewidział określona ilość wina w codziennej diecie mnichów, a także pozbawianie tego trunku jako karę. Por. S. Pater Benedictus, Regula, 40, 533-534; 43, 576, [w:] Patrologiae cursus completus, series latina, ed. J.-P. Migne, vol. LXVI, Paris 1847. Por. też M.W. Ad a m s o n, Food in medieval times, Westport-London 2004, s. 49-50. 
biskup Ursycyn $z$ Cahors. W jej ramach mial m.in. przez trzy lata nie pić wina ${ }^{31}$, co oznacza, że powstrzymywanie się od niego było w ówczesnych realiach dotkliwa karą. Powstrzymywanie się od wina było zresztą dla Grzegorza tak nietypowe, że wiąże się u niego ze skrajnymi przykładami ascezy, zawsze godnymi podkreślenia. Wina nie pili np. Julian, duchowny słynący z czynienia cudów ${ }^{32}$, pustelnik Patroklus ${ }^{33}$ czy Jan, bardzo wstrzemięźliwy młodzieniec oddany na nauki do przyszłego biskupa Rodez, Innocentego ${ }^{34}$.

Dieta zaprawiajacych się w ascezie ludzi jest zresztą dla Grzegorza okazją do poczynienia kilku interesujacych $z$ naszej perspektywy uwag nie tylko pod katem spożycia wina. Prócz niebudzacych zdziwienia informacji, że unikali oni jedzenia mięsa ${ }^{35}$, biskup Tours pisze o niejakim Hospicjuszu żyjącym w pobliżu Nicei, że jadł tylko suchy chleb $z$ odrobina daktyli, a w czasie Wielkiego Postu gotował korzenie nieokreślonych egipskich ziól, otrzymywanych od kupców i wypiwszy uzyskany wywar, zjadał je ugotowane ${ }^{36}$. We fragmencie tym zwracaja uwage dwie rzeczy. Po pierwsze, palmy daktylowe nie rosły na galijskich wybrzeżach Morza Sródziemnego. Wspomniany pustelnik musiał się więc żywić owocami importowanymi. Wydaje się przy tym, że $z$ racji na skrajną wstrzemięźliwość, w jakiej żył ( $z$ którą nie kłóci się sam pomysł jedzenia daktyli, ponieważ już pierwsi egipscy i palestyńscy anachoreci i cenobici, jak św. Antoni, bazowali na tych bogatych w cukry, tłuszcze i witaminy owocach ${ }^{37}$, a bliskowschodnie tradycje przenikały do Galii od dawna choćby za sprawą Jana Kasjana ${ }^{38}$ ),

${ }^{31}$ Grzegorz z Tours, Historiae, VIII, 20.

${ }^{32}$ Grzegorz $z$ Tours, Historiae, IV, 32.

${ }^{33}$ Grzegorz z Tours, Historiae, V, 10.

${ }^{34}$ Grzegorz z Tours, Historiae, X, 8.

35 Czynili tak przytoczeni już Julian i Patroklus, choć można się domyślać, że również inni asceci wspomniani przez Grzegorza ograniczali spożycie mięsa.

${ }^{36}$ Grzegorz z Tours, Historiae, VI, 6.

${ }^{37}$ Por. M. Dembińska, Diet: A comparison of food consumption between some eastern and western monasteries in the $4^{\text {th }}-12^{\text {th }}$ centuries, "Byzantion” 1985 , vol. LV, s. 434-437. Z kolei piszac o regule ustanowionej przez Pachomiusza, autorka sugeruje, że daktyle były wymieniane przez mniszą społeczność na inne dobra $z$ zewnattrz lub trzymane do jedzenia na specjalne okazje (M. D e m bińs ka, op. cit., s. 441-442).

38 Jan Kasjan, który ostatnie dwudziestolecie IV w. spędził na Bliskim Wschodzie i w Egipcie, przesiąkając ideałami tamtejszych anachoretów, w początkach wieku V ruszył na zachód, a około 410 r. osiadł w Galii Narbońskiej, gdzie zainicjował ruch monastyczny i silnie na niego wpływał. Por. C. Stewart, $\mathrm{Ka}$ sjan mnich, przekł. T. Lubowiecka, Kraków 2004, passim, zwłaszcza 154-156; 
nie sięgałby po produkty egzotyczne, rzadko dostępne i drogie, słowem: luksusowe. Jeśli tak, to oznaczałoby, że w VI-wiecznej Galii, a przynajmniej w jej najbardziej na południe wysuniętej części, sprowadzone zza morza daktyle nie były rzadkością. Potwierdzać może to wzmianka, jaka na ich temat zamieścił kilka dekad wcześniej w swym De observatione ciborum Antimus ${ }^{39}$. Po drugie, Grzegorz pisze o egipskich ziołach, nie precyzując, o jakie rośliny chodzi. Niestety, trudno na podstawie tego fragmentu snuć przypuszczenia dotyczace identyfikacji gatunków, zwłaszcza że nie ma pewności co do precyzji sformułowania użytego przez autora Historiae $^{40}$. Ciekawym odniesieniem do tego passusu wydaja się słowa Wenancjusza Fortunata, który w jednym $z$ wierszy wspomina, że podróżni mają w zwyczaju przywozić „zza morza” zagraniczne przysmaki, by uczty były wykwintniejsze ${ }^{41}$, co zresztą zdaje się być zjawiskiem o korzeniach sięgających w znacznie bardziej zamierzchła przeszłość. Jedzenie było też częstym podarkiem wręczanym sobie przez osoby duchowne ${ }^{42}$.

Z kolei diakon Wulfilach, który opowiedział Grzegorzowi swoją historię, miał niegdyś radykalnie umartwiać się, żyjąc na słupie, póki

A. N o c oń, Jan Kasjan, Kraków 2004, passim. Oczywiście nie był on jedynym, który wschodnie tradycje przeszczepiał na zachodni grunt. Wymienić należałoby tu choćby Atanazego, ale też wielu anonimowych pielgrzymów. Por. C.H. Law re n ce, Medieval monasticism. Forms of religious life in Western Europe in the Middle Ages, London-New York 1992, s. 11-17.

${ }^{39}$ Antimus, De observatione ciborum, 92. Wprawdzie Antimus podążał w swej pracy za silnie osadzonym $\mathrm{w}$ realiach śródziemnomorskich modelem układu tematycznego, wypracowanym przez Galena i kontynuowanym np. u Orybazjusza, jednak równocześnie wyraźny jest u niego wpływ lokalnych obyczajów kulinarnych kraju, w którym pisał. Stąd jego passus o daktylach nie musi być jedynie świadectwem oderwanego od galijskiej rzeczywistości trzymania się tekstu uznanych autorytetów, lecz śladem ich faktycznej obecności w państwie Franków.

40 Znamy wiele roślin jadanych w Egipcie przez tamtejszych mnichów u schyłku epoki antyku i później. Ich zestawienie (por. B. C a s e au, Nourritures terrestres, nourritoures célestes. La culture alimentaire à Byzance, Paris 2015, s. 278-279) nie pomaga jednak w rozwikłaniu zagadki egipskich ziół Hospicjusza. Większość bowiem roślin, których korzenie wykorzystywano nad Nilem, znana była około VI w. w całym basenie Morza Śródziemnego. Nieco inaczej rzecz mogła się mieć z kolibłem egipskim (Balanites aegyptiaca [L.] Delile), którego korzenie stosowano w Egipcie i który nie był powszechnie występująca w rejonie śródziemnomorskim rośliną.

${ }^{41}$ Wenancjusz Fortunat, Carmina, VII, 24 b.

${ }^{42}$ Por. D. Shanzer, Bishops, letters, fast, food, and feast in later Roman Gaul, [w:] Society and culture in late antique Gaul. Revisiting the sources, eds. R.W. Mathisen, D. Shanzer, Aldershot 2001, s. 217-236. 
dostojnicy kościelni nie wyperswadowali mu niedorzeczności naśladowania wszystkich wschodnich wzorów w klimacie środkowej Galii. Poszcząc, Wulfilach jadał tylko chleb z kapustą i pił wodę ${ }^{43}$. W przeciwieństwie do nieco zaskakujacego jadłospisu Hospicjusza, wyżywienie Wulfilacha jawi się jako typowe - choć skrajnie uproszczone i zubożone - dla stron, w których żył. Kapusta była od wieków jedną z podstaw diety ludów zamieszkujących Europę ${ }^{44}$, a korzystny wpływ jej konsumpcji na zdrowie podkreślali liczni antyczni i wczesnobizantyńscy autorzy zajmujący się medycyną i agronomia: od Katona ${ }^{45}$, przez Galena ${ }^{46}$, Orybazjusza ${ }^{47}$, Aecjusza $z$ Amidy $^{48}$, po anonimowego autora Geoponika ${ }^{49}$, choć Anthimus stwierdził, że powinno się ja jeść tylko zimą ${ }^{50}$. Niestety, w swojej opowieści o Wulfilachu Grzegorz nie wdaje się w szczegóły. Nie wiemy w związu $z$ tym, czy asceta żywił się kapusta surową czy gotowana i czy okraszał ja jakimiś dodatkowymi składnikami, które znamy $z$ antycznych przekazów, jak oliwa, ruta, kolendra czy ocet zmieszany $z$ miodem ${ }^{51}$.

${ }^{43}$ Grzegorz z Tours, Historiae, VIII, 15.

${ }^{44}$ D. Zohary, M. Hopf, Domestication of plants in the Old World. The origin and spread of cultivated plants in West Asia, Europe and in the Nile Valley, Oxford 1993, s. 186; A. Dalby, Food in the ancient world from $A$ to $Z$, LondonNew York 2003, s. 67; J.P. Alcock, Food in the ancient world, Westport-London 2006, s. 50; J.M. Wilkins, S. Hill, Food in the ancient world, MaldenOxford 2006, s. 134-138.

${ }^{45}$ M. Porci Catonis de agri cultura, 156, 1-157, 10, rec. H. Keil, Lipsiae 1895 [dalej: Kato n, De agri cultura].

${ }^{46}$ Galeni de alimentorum facultatibus libri III, 630, 16-633, 8, vol. VI; 460, 10-461, 11, vol. VI, [w:] Claudii Galeni opera omnia, ed. C.G. Kühn, vol. VI, Lipsiae 1823 [dalej: Galen, De alimentorum facultatibus].

${ }^{47}$ Orybazjusz, Collectiones medicae, II, 5, 1, 1-3, 2; IV, 4, 1, 1-5, 2.

${ }_{48}$ A ecjusz z Amidy, Iatricorum libri, I, 221, 7-15.

49 Geoponica sive Cassiani Bassi Scholastici de re rustica eclogae, XII, 17, 2-11, rec. H. Beckh, Lipsiae 1895.

${ }^{50}$ Antimus, De observatione ciborum, 50. Jedzenie kapusty w lecie powoduje, wedle tego autora, powstawanie w organizmie człowieka czarnej żółci.

${ }^{51} \mathrm{O}$ jedzeniu surowej kapusty, do smaku maczanej niekiedy w occie, pisał Kat on (De agri kultura, 156, 1), choć wydaje się, że powszechniej jadano ja po ugotowaniu, co zapisał też A tenajos $z$ Naukratis (Athenaei Naucratitae deipnosophistarum libri XV, IX, 370, e-f [10, 16-32], rec. G. Keibel, vol. I-III, Lipsiae-Berolini 1887-1890, dalej: A tenajos, Deipnosophistae), ale najwięcej na temat możliwości jej podania napisano w anonimowym De re coquinaria (Apicius. A critical edition with an introduction and an English translation of the Latin recipe text Apicius, III, 9, 1-6; III, 10, 2; III, 21, 3; IV, 2, 7; IV, 4, 2; V, 5, 2; VIII, 7, 14, eds Ch. Grocock, S. Grainger, Blackawton-Totnes 2006). 
Wreszcie o wspomnianym już młodzieńcu imieniem Jan, który przebywał u biskupa Innocentego, Grzegorz pisze, że w ramach postów nie tylko nie pił wina, o czym wspomnieliśmy, lecz także w miejsce chleba pszennego jadał pieczywo jęczmienne ${ }^{52}$. Koresponduje to $z$ innym passusem Historiae, w którym frankijski król Guntram nakazał mieszkańcom trawionej zaraza Marsylii pokutować za grzechy w nadziei na odzyskanie Bożej przychylności. Jednym $z$ elementów tej pokuty miało być jedzenie chleba $z$ jęczmienia zamiast $z$ pszenicy ${ }^{53}$. Oba te fragmenty wskazuja, że w drugiej połowie VI w. w rządzonej już przez Franków Galii chleb pszenny był uważany za pokarm lepszy niż chleb jęczmienny i to do tego stopnia, że spożywanie tego drugiego wiązało się z poważnymi wyrzeczeniami i nie było sytuacja codzienną. Jest to ważne świadectwo potwierdzające obserwowana już w społeczeństwach antycznych generalną i powolną tendencję do zastępowania pokarmów jęczmiennych pszennymi ${ }^{54}$. Zjawisko to wynikało $z$ czynników, takich jak smak i jakość uzyskiwanych wypieków, ale podparte było ówczesną teoria medyczną. Chociaż bowiem jęczmień był przez lekarzy doceniany i zalecany, to w gradacji zbóż pod względem jakości i zalet dla zdrowia zawsze u autorów dzieł medycznych ustępował pszenicy zwyczajnej ${ }^{55}$. Co więcej, opinia na temat przewagi pszenicy

${ }^{52}$ Grzegorz z Tours, Historiae, X, 8.

${ }^{53}$ Grzegorz z Tours, Historiae, IX, 21.

${ }^{54}$ Szerzej zjawisko to dotyczy w ogóle zastępowania przez pokarmy oparte na pszenicy zwyczajnej tych zrobionych ze wszystkich pozostałych zbóż, od innych gatunków pszenic, przez jęczmień i owies, po proso. Nie oznacza jednak zupełnego przestawienia się ówczesnych europejskich społeczeństw na wyroby pszenne, a jedynie stały - w skali wielkich obszarów, jak prowincje czy królestwa - i powolny wzrost ich roli względem nadal spożywanych, ale $z$ upływem stuleci tracacych znaczenie produktów $z$ innych zbóż. Te ostatnie, zwłaszcza jęczmień, pozostawały na interesujących nas obszarach istotnymi uprawami, ważnymi dla utrzymania żywego inwentarza i ludzkich społeczności (np. w przypadku nieurodzaju pszenicy) na długo po VI w., którym się tu zajmujemy. Por. C. M orris o n, J.-P. So dini, The sixth-century economy, [w:] The economic history of Byzantium, ed. A. Laiou, vol. II, Washington 2002, s. 195-196; J. Rodzińs ka-Nowak, Gospodarka żywnościowa ludności kultury przeworskiej, Kraków 2012, s. 100-104; I. A nag nostakis, Byzantine diet and cuisine. In between ancient and modern gastronomy, [w:] Flavours and delights. Tastes and pleasures of ancient and Byzantine cuisine, ed. I. Anagnostakis, Athens 2013, s. 50.

${ }_{55}$ Por. M. Kokoszko, K. Jagusiak, Z. Rzeźnicka, Dietetyka i sztuka kulinarna antyku i wczesnego Bizancjum (II-VII w.), cz. 1 (Zboża i produkty zbożowe w źródłach medycznych antyku i wczesnego Bizancjum [II-VII w.]), Łódź 2014, s. 332-337. 
nad jęczmieniem była tak rozpowszechniona, że niekiedy karmienie jęczmieniem zamiast pszenica mogło być forma kary. W armii rzymskiej, co podkreślają autorzy źródeł pisanych od czasów republiki po okres dominatu, tacy jak Polibiusz ${ }^{56}$, Swetoniusz ${ }^{57}$, Plutarch ${ }^{58}$, Kasjusz Dion ${ }^{59}$, Frontyn ${ }^{60}$ czy Wegecjusz ${ }^{61}$, oddziałom, które nie wykonały rozkazu, stchórzyły w obliczu wroga bąź wykazały inną formę niesubordynacji, odbierano czasem racje pszenicy i zastępowano je za karę jęczmieniem niekiedy nawet na całe lata. Poza tym w stuleciu, którym się zajmujemy, konsumpcja pszenicy była tak rozpowszechniona, że jedzenie jęczmienia bądź innych zbóż jako podstawy jadłospisu mogło wręcz, w oczach przedstawicieli kultury grecko-rzymskiej, graniczyć z barbarzyństwem, jak w opisie zwyczajów Maurów przedstawionym przez Prokopiusza z Ceza$\mathrm{rei}^{62}$. Sięganie po chleb jęczmienny w ramach pokuty czy umartwiania się nie powinno więc dziwić, korzenie tego zjawiska tkwiły bowiem głęboko w świadomości ówczesnych społeczeństw ${ }^{63}$.

W Historiae Grzegorza $z$ Tours znajdujemy też kilka niezwiązanych ze sobą i niedajacych się zakwalifikować do jednej grupy wzmianek o konkretnych pokarmach. Będą one ostatnimi, jakie omówimy. Nie wnosza wiele nowego do naszej wiedzy na temat jadłospisu mieszkańców VI-wiecznej Galii, ale warte sa przytoczenia. Dwukrotnie Grzegorz wspomina o drobiu przygotowywanym do jedzenia, raz u króla Chilperyka ${ }^{64}$, a w innym miejscu, gdy przytacza dzieje kucharza imieniem Leon, służącego u pewnego możnego Franka i wyczarowującego dlań wspaniałe potrawy ${ }^{65}$. O ile

56 Polibius, The histories, VI, 3-39, ed. W.R. Paton, vol. I, Cambridge, Mass. 1998. Z przekazu wynika też, że jęczmień wykorzystywano w armii przede wszystkim jako paszę dla zwierząt.

${ }^{57}$ Suetonius' The lives of the twelve caesars, II, 24, ed. J.C. Rolfe, London 1913-1914.

58 Plutarch, Marcellus, 25, 10, 2, [w:] P1utarch, Lives, ed. B. Perrin, vol. V, Cambridge, Mass. 1917.

59 Dio Cas sius, Roman history, XLIX, 38, 4, ed. E. Cary, Cambridge, Mass. 1914.

${ }^{60}$ Frontinus, Strategems, IV, 1, 25; IV, 1, 37, [w:] Frontinus, Strategems. Aqueducts of Rome, ed. C.E. Bennett, Cambridge, Mass. 1925.

${ }^{61}$ Vege tiu s, Epitome of military art, I, 13, transl. N.P. Milner, Liverpool 2001.

${ }^{62}$ Procopius with an English translation, IV, 6, 13, transl. H.B. Dewing, vol. I-VI, London-New York 1914-1928.

${ }^{63}$ Por. J.L. Tea11, The grain supply of the Byzantine Empire, 330-1025, „Dumbarton Oaks Papers” 1959, vol. XIII, s. 99.

${ }^{64}$ Grzegorz z Tours, Historiae, V, 18.

${ }^{65}$ Grzegorz $z$ Tours, Historiae, III, 15. 
w drugim przypadku nie padają, niestety, żadne bliższe szczegóły na temat tego, w jaki sposób kucharz przygotowywał kury i z czym je podawał (choć można się domyślać, że było to coś wykwintnego, goście bowiem zachwycali się jego kunsztem ${ }^{66}$ ), o tyle pisząc o zastawionym jadłem stole królewskim, Grzegorz wspomina, że były tam dania $z$ drobiu i ciecierzycy. Roślina ta, w Starym Świecie znana od czasów najdawniejszych, do epoki Grzegorza doczekała się różnych kulinarnych zastosowań, które częściowo znamy dzięki anonimowemu traktatowi De re coquinaria. Bywała nie tylko ingrediencja gęstych i pożywnych zup ${ }^{67}$, lecz także swego rodzaju sałatek $^{68}$. Jadano ją też samą ${ }^{69}$, gotujac lub prażac ${ }^{70}$ i podawano na deser $^{71}$. O jej popularności świadczy poniekąd również to, że doczekała się obszernej charakterystyki dietetycznej w literaturze poświęconej lecznictwu, w której konsekwentnie podkreślano jej zalety, takie jak pożywność ${ }^{72}$, zdolność do oczyszczania ${ }^{73}$ i rozgrzewania ${ }^{74}$ organizmu czy diuretyczność ${ }^{75}$. Niestety, w omawianym fragmencie

${ }^{66}$ Warto nadmienić, że w VI-wiecznej Galii, przynajmniej wśród wykształconych ludzi, nie było obce imię niemal legendarnego rzymskiego smakosza Apicjusza, któremu przypisywano autorstwo książki kucharskiej znanej jako De re coquinaria (dziś wiemy, że powstała kilka stuleci po jego śmierci i datujemy ja na IV/V w. n.e.). Por. Wenancjus z Fortunat, Carmina, VII, 2. Nie można wykluczyć, że i sam traktat stanowił inspirację dla bardziej wyrobionych kucharzy.

${ }^{67}$ De re coquinaria, IV, 4, 2; V, 5, 2.

${ }_{68}$ De re coquinaria, $\mathrm{V}, 8,1-2$.

69 De re coquinaria, $\mathrm{V}, 8,2$.

70 Antimus, De observatione ciborum, 68. W tej formie ciecierzyca była przysmakiem od czasu do czasu urozmaicajacym jadłospis ciężko poszczących pustelników, por. Joannis Cassiani Collationum, VIII, 1, [w:] Patrologiae cursus completus, series latina, ed. J.-P. Minge, vol. XLIX, Paris 1846.

${ }^{71}$ Atenajos, Deipnosophistae, IV, 138, a (14, 40); XIV, 642 e-f (50, 8-14); XIV, 649 a $(60,17-20)$.

${ }^{72}$ Galen, De alimentorum facultatibus, 533, 8-16, vol. VI; Orybazjusz, Collectiones medicae, I, 20, 1, 1-3, 4; A ecjusz z Amidy, Iatricorum libri, II, 250, 1-21.

${ }^{73}$ Galen, De alimentorum facultatibus, 533, 8-16, vol. VI; Atenajos, Deipnosophistae, II, 55 b (44, 43-44); Orybazjusz, Collectiones medicae, XIV, 47, 1, 1-3, 4; Aecjusz z Amidy, Iatricorum libri, II, 260, 1-26; Paulus Aegineta, I, 79, 1, 1-15, ed. I.L. Heiberg, vol. I-II, Lipsiae-Berolini 1921-1924.

${ }^{74}$ Orybazjus z, Collectiones medicae, XIV, 14, 1, 1-17, 2; A e cjus z z Amid y, Iatricorum libri, II, 198, 1-13.

${ }_{75}$ Dioscuridis peri haplon farmakon, II, 119, 1, 1-5, 10, [w:] Pedanii Dioscuridis Anazarbei de materia medica libri quinque, ed. M. Wellmann, vol. III, Berolini 1914; Atenajos, Deipnosophistae, II, 55 b (44, 43-44); Orybazjusz, Collectiones medicae, XIV , 49, 1, 1-12, 4. Por. An timu s, De observatione ciborum, 73. 
Historiae znów brakuje informacji co do sposobu przyrządzenia samego mięsa kur. Pisany nieco wcześniej dla frankijskiego króla Teuderyka traktacik De observatione ciborum Antimusa zaleca ich gotowanie, a także pieczenie jako zdrowe ${ }^{76}$, w innym zaś swoim dziele sam Grzegorz wspomina, jak ludzie po prostu ugotowali kurę $\mathrm{w}$ garnku ${ }^{77}$ i zapewne którąs $z$ podanych metod obróbki termicznej zastosowano w obu przypadkach spisanych w Historiae. Co do sposobów przyprawienia drobiu, to skalę możliwości nadal dostępnych zarówno elicie galijskiej nawet po upadku Cesarstwa Zachodniorzymskiego, jak i równie chętnie korzystajacemu $z$ uciech stołu możnowładztwu frankijskiemu ${ }^{78}$ oddaje wspomniana już, skomponowana około 150-200 lat wcześniej, książka kucharska De re coquinaria, w której zachowało się wiele przepisów na tego typu dania ${ }^{79}$.

W podsumowaniu chcielibyśmy zwrócić uwagę na kilka kwestii. Po pierwsze, w Historiae Grzegorza $z$ Tours można natrafić na stosunkowo liczne wzmianki poświęcone jedzeniu i piciu. Nie jest to coś niespotykanego na tle ówczesnej historiografii. Obszerne źródła narracyjne powstałe w antyku i średniowieczu (do jakich dzieło Grzegorza się zalicza) od czasu do czasu zaskakuja zainteresowanego historią żywienia czytelnika pobudzającymi wyobraźnię i urozmaicającymi tok opowiadania passusami $z$ tej tematyki. Jeśli coś wyróżnia pod tym względem dzieło Grzegorza, to liczba tego rodzaju wzmianek i ich charakter. $Z$ reguły pojawiaja się w związku $z$ opisami skrajnych zachowań: przesady w piciu wina i jej konsekwencji oraz postów, mając przy tym moralnie wartościujący

76 Antimus, De observatione ciborum, 23.

77 Sancti Georgii Florentii Gregorii episcopus libri miraculorum, 97, 830 b-c, [w:] Patrologiae cursus completus, series latina, ed. J.-P. Migne, vol. LXXI, Paris 1849.

78 Trzeba pamiętać, że jedzenie i picie bywało w społeczeństwie ówczesnej Galii (a także w innych krajach i nie tylko w tej epoce) elementem manifestowania statusu. Menu władców i możnych było bardziej urozmaicone i zdecydowanie mniej zależne od kaprysów sił natury i ludzkich postępków powodujących głód wśród mas. Biskup Grzegorz należał do najwyższych elit państwa i wzmianki w jego pismach o charakterze kulinarnym dają temu - trudno powiedzieć na ile świadomie wyraz. Por. Y. Hen, Food and drink in Merovingian Gaul, [w:] Tätigkeitsfelder und Erfahrungshorizonte des ländlichen Menschen in der frühmittelalterlichen Grundherrschaft (bis ca. 1000). Festschrift für Dieter Hägermann zum 65. Geburstag, hrsg. B. Kasten, Stuttgart 2006, s. 105-107.

${ }^{79}$ Por. De re coquinaria, VI, 8, 1-15. 
charakter. Znacznie mniej jest wzmianek dotyczących zwyczajnych praktyk kulinarnych, przy czym te, które są, dotyczą głównie politycznych elit państwa Franków, ponieważ jedzenie mas zwykłych ludzi, tak germańskiego, jak i galijskiego pochodzenia, interesuje Grzegorza właściwie tylko w przypadku opisywania klęsk głodu, gdy informuje o tym, co spożywały one w obliczu skrajnego niedożywienia i zagrożenia głodową śmiercią ${ }^{80}$. Nawet jednak relacje dotyczące owych dwóch skrajności moga pozwolić na wysunięcie pewnych wniosków dotyczących diety mieszkańców VI-wiecznej Galii, co staraliśmy się w naszym artykule pokazać. $Z$ lektury Historiae wyłania się obraz kraju, o którym można powiedzieć, że mimo głębokich i wielowymiarowych przemian, jakie w nim zaszły w V i VI w., zwiazanych $z$ inwazjami ludów zza Renu i upadkiem rzymskiego panowania, zachował większość kulinarnych zwyczajów i przyzwyczajeń. I choć znajdujemy tam wiele mówiąca informację o biskupie Eteriuszu jedzącym posiłek na leżąco, zamiast siedząc, podana $\mathrm{w}$ tonie wskazujacym na niezwykłość tej, kojarzonej $z$ antykiem grecko-rzymskim postawy ${ }^{81}$, a obraz nowych tendencji wzmacniaja przekazy innych autorów, jak ten Antimusa o niezwykłej predylekcji Franków do surowego boczku ${ }^{82}$ czy Sydoniusza Apolinarego o woni masła dochodzącej od Burgundów ${ }^{83}$, $z$ relacji Grzegorza odmalowuje się przed nami świat, w którym nadal podstawę wyżywienia stanowić musiał pszenny chleb, wino utrzymało swą popularność, a codziennym do niego dodatkiem były warzywa, w tym rośliny strączkowe. Uzasadnione wydaje się

${ }^{80}$ Por. Grzegorz z Tours, Historiae, VI, 36. Biskup Tours nie był w tym względzie odosobniony. Wystarczy wspomnieć Antimusa, który w swym dziele opisał wiele produktów, których zapewne przeciętny mieszkaniec Galii nie widywał na co dzień. Ujmując rzecz ogólnie, teksty kulinarne i medyczne (a także inne) skierowane były do elit, które mogły sobie pozwolić na urozmaicone menu. Por. R. Nadeau, Body and soul, [w:] A cultural history of food in antiquity, ed. P. Erdkamp, London-New York 2016, s. 152.

${ }^{81}$ Grzegorz z Tours, Historiae, VI, 36.

82 Antimus, De observatione ciborum, 14.

83 Sydoniusz Apolinary, Carmina, XII, 369. Konsumpcja masła miała dla Greków, Rzymian i ludzi aspirujacych do przynależności do ich kultury (w czym zwyczaje kulinarne odgrywały niemała rolę) marginalne znaczenie. Korzystanie $z$ niego kojarzone było $z$ barbarzyńskością. Por. Z. Rzeźnicka, M. Kokoszko, Dietetyka $i$ sztuka kulinarna antyku $i$ wczesnego Bizancjum (II-VII w.), cz. 3 (Ab

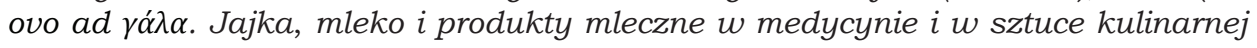
[I-VII w.]), Łódź 2016, s. 170-182. 
w związku z tym stwierdzenie, że i większość innych, nieopisanych wprawdzie przez biskupa Tours, ale znanych skądinąd zwyczajów kulinarnych utrzymywała się w VI-wiecznej Galii.

\section{Bibliografia}

\section{ŹRÓDEA DRUKOWANE}

Aetii Amideni libri medicinales I-VIII, ed. A. Olivieri, Lipsiae-Berolini 1935-1950. Anthimus, De observatio ciborum, ed. S.H. Weber, Leiden 1924.

Apicius. A critical edition with an introduction and an English translation of the Latin recipe text Apicius, eds Ch. Grocock, S. Grainger, Blackawton-Totnes 2006.

Athenaei Naucratitae deipnosophistarum libri XV, rec. G. Keibel, vol. I-III, LipsiaeBerolini 1887-1890.

C. Iuli Commentarii Rerum in Gallia Gestarum VII A. Hirti Commentarius VII, ed. T. Rice Holmes, Oxonii 1914.

C. Sollii Apollinaris Sidonii carmina, [w:] Patrologiae cursus completus, series latina, ed. J.-P. Migne, vol. LVIII, Paris 1862, s. 639-748.

C. Sollii Apollinaris Sidonii epistulae, [w:] Patrologiae cursus completus, series latina, ed. J.-P. Migne, vol. LVIII, Paris 1862, s. 443-639.

Dio Cassius, Roman history, ed. E. Cary, Cambridge, Mass. 1914.

Dioscuridis peri haplon farmakon, [w:] Pedanii Dioscuridis Anazarbei de materia medica libri quinque, ed. M. Wellmann, vol. III, Berolini 1914, s. 149-326.

Frontinus, Strategems, [w:] Frontinus, Strategems. Aqueducts of Rome, ed. C.E. Bennett, Cambridge, Mass. 1925, s. 1-329.

Galeni de alimentorum facultatibus libri III, [w:] Claudii Galeni opera omnia, ed. C.G. Kühn, vol. VI, Lipsiae 1823, s. 453-748.

Geoponica sive Cassiani Bassi Scholastici de re rustica eclogae, rec. H. Beckh, Lipsiae 1895.

Gregorii Turonensis Libri historiarum X, eds B. Krusch, W. Levinson, Hannover 1884.

Joannis Cassiani Collationum, [w:] Patrologiae cursus completus, series latina, ed. J.-P. Minge, vol. XLIX, Paris 1846, s. 477-1328.

M. Porci Catonis de agri cultura, rec. H. Keil, Lipsiae 1895.

Oribasii collectionum medicarum reliquiae, ed. I. Raeder, vol. I-IV, Lipsiae-Berolini 1928-1933.

P. Cornelius Tacitus, Germania. Publiusz Korneliusz Tacyt, Germania, przekł. T. Płóciennik, Poznań 2008.

Paulus Aegineta, ed. I.L. Heiberg, vol. I-II, Lipsiae-Berolini 1921-1924.

Pedanii Dioscuridis Anazarbei de materia medica libri $V$, ed. M. Wellmann, vol. I-III, Berolini 1906-1914. 
Plutarch, Marcellus, [w:] Plutarch, Lives, ed. B. Perrin, vol. V, Cambridge, Mass. 1917, s. 436-523.

Polibius, The histories, ed. W.R. Paton, vol. I, Cambridge, Mass. 1998.

Procopius with an English translation, transl. H.B. Dewing, vol. I-VI, London-New York 1914-1928.

S. Pater Benedictus, Regula, [w:] Patrologiae cursus completus, series latina, vol. LXVI ed. J.-P. Migne, Paris 1847, s. 215-932.

Sancti Georgii Florentii Gregorii episcopus libri miraculorum, [w:] Patrologiae cursus completus, series latina, ed. J.-P. Migne, vol. LXXI, Paris 1849, s. 705-828.

Suetonius' The lives of the twelve caesars, ed. J.C. Rolfe, London 1913-1914.

Vegetius, Epitome of military art, transl. N.P. Milner, Liverpool 2001.

Venanti Fortunati carmina, [w:] Venanti Honori Clementiani Fortunati presbyteri italici opera pedestria, rec. F. Leo, Berolini 1881, s. 1-292.

Venanti Fortunati vitae sancte Redegundis, [w:] Venanti Honori Clementiani Fortunati presbyteri italici opera pedestria, rec. B. Krusch, Berolini 1885, s. 38-49.

\section{Opracowania}

Adamson M.W., Food in medieval times, Westport-London 2004.

Alcock J.P., Food in the ancient world, Westport-London 2006.

Anagnostakis I., Byzantine diet and cuisine. In between ancient and modern gastronomy, [w:] Flavours and delights. Tastes and pleasures of ancient and Byzantine cuisine, ed. I. Anagnostakis, Athens 2013, s. 43-63.

Bailey L., "These Are Not Men": Sex and Drink in the Sermons of Caesarius of Arles, „Journal of Early Christian Studies” 2007, vol. XV, No. 1, s. 23-43.

Caseau B., Nourritures terrestres, nourritoures célestes. La culture alimentaire à Byzance, Paris 2015.

Dalby A., Food in the ancient world from A to Z, London-New York 2003.

Dembińska M., Diet: A comparison of food consumption between some eastern and western monasteries in the $4^{\text {th }}-12^{\text {th }}$ centuries, "Byzantion” 1985, vol. LV, s. 431-462.

Dominé A., Supp E., Sautter U., Faßbender W., Burgundia, [w:] Wino, ed. A. Dominé, przekł. Z. Zawadzki, Ożarów Mazowiecki 2008, s. 180-209.

Goffart W., The Narrators of Barbarian History (A.D. 550-800). Jordanes, Gregory of Tours, Bede and Paul the Deacon, Princeton 1988.

Heinzelmann M., Gregory of Tours. History and Society in the Sixth Century, trans. Ch. Carroll, Cambridge-New York 2006.

Heinzelmann M., Gregory of Tours. The Elements of a Biography, [w:] A Companion to Gregory of Tours, ed. A.C. Murray, Boston 2015, s. 5-34.

Hen Y., Food and drink in Merovingian Gaul, [w:] Tätigkeitsfelder und Erfahrungshorizonte des ländlichen Menschen in der frühmittelalterlichen Grundherrschaft (bis ca. 1000). Festschrift für Dieter Hägermann zum 65. Geburstag, hrsg. B. Kasten, Stuttgart 2006, s. 99-110. 
James E., Introduction, [w:] Gregory of Tours, Life of the Fathers, trans. E. James, Liverpool 1991, Translated Texts for Historians, 1, s. IX-XXV.

Kokoszko M., Jagusiak K., Rzeźnicka Z., Dietetyka i sztuka kulinarna antyku $i$ wczesnego Bizancjum (II-VII w.), cz. 1 (Zboża i produkty zbożowe w źródłach medycznych antyku i wczesnego Bizancjum [II-VII w.]), Łódź 2014.

Lawrence C.H., Medieval monasticism. Forms of religious life in Western Europe in the Middle Ages, London-New York 1992.

Leclercq H., Grégoire de Tours, [w:] Dictionnaire d'archéologie chrétienne et de liturgie, t. VI, p. 2, Paris 1925, k. 1711-1753.

Mayerson P., The wine and vineyards of Gaza in the Byzantine period, „Bulletin of the American Schools of Oriental Research" 1985, No. 257, s. 75-80.

Morrison C., Sodini J.-P., The sixth-century economy, [w:] The economic history of Byzantium, ed. A. Laiou, vol. II, Washington 2002, s. 171-220.

Murray A.C., The Composition of the Histories of Gregory of Tours and Its Bearing on the Political Narrative, [w:] A Companion to Gregory of Tours, ed. A.C. Murray, Boston 2015, s. 61-101.

Nadeau R., Body and soul, [w:] A cultural history of food in antiquity, ed. P. Erdkamp, London-New York 2016, s. 145-162.

Nocoń A., Jan Kasjan, Kraków 2004.

Rodzińska-Nowak J., Gospodarka żywnościowa ludności kultury przeworskiej, Kraków 2012.

Rzeźnicka Z., Kokoszko M., Dietetyka i sztuka kulinarna antyku $i$ wczesnego

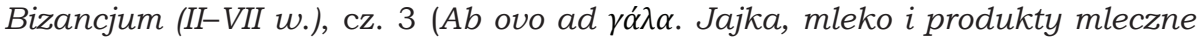
$w$ medycynie $i w$ sztuce kulinarnej [I-VII w.), Łódź 2016.

Shanzer D., Bishops, letters, fast, food, and feast in later Roman Gaul, [w:] Society and culture in late antique Gaul. Revisiting the sources, eds. R.W. Mathisen, D. Shanzer, Aldershot 2001, s. 217-236.

Sikorski D.A., Wstęp, [w:] Grzegorz z Tours, Historie. Historia Franków, przekł. K. Liman, T. Richter, Kraków 2002, s. 7-44.

Stewart C., Kasjan mnich, przekł. T. Lubowiecka, Kraków 2004.

Teall J.L., The grain supply of the Byzantine Empire, 330-1025, „Dumbarton Oaks Papers" 1959, vol. XIII, s. 87-139.

Thurmond D., From vines to wines in classical Rome. A handbook of viticulture and oenology in Rome and the Roman West, Leiden-Boston 2017.

Unwin T., Wine and the vine: An historical geography of viticulture and the wine trade, London-New York 2005.

Wilkins J.M., Hill S., Food in the ancient world, Malden-Oxford 2006.

Wood I., Gregory of Tours, Bangor 1994.

Zohary D., Hopf M., Domestication of plants in the Old World. The origin and spread of cultivated plants in West Asia, Europe and in the Nile Valley, Oxford 1993. 
NOTKA O AUTORACH:

Dr Krzysztof Jagusiak - od 2011 r. zatrudniony w Centrum Ceraneum, zwiazany $z$ Katedra Historii Bizancjum UŁ, gdzie pod kierunkiem prof. Macieja Kokoszki napisał doktorat (2015) poświęcony spożyciu zbóż i ich zastosowaniu w medycynie grecko-rzymskiej i wczesnobizantyńskiej.

Zainteresowania naukowe: różne aspekty gastronomii i medycyny pomiędzy I a VII w. n.e., w tym ustalenie roli warzyw w kuchni i lecznictwie, enologia, analiza przekazów autorów chrześcijańskich na temat jedzenia.

అ krzysztof_jagusiak@o2.pl

Dr Jolanta Dybała - doktor nauk humanistycznych w zakresie historii. W 2011 r. na Wydziale Filozoficzno-Historycznym Uniwersytetu Łódzkiego obroniła rozprawę doktorska pt. Ideat kobiety $w$ greckiej literaturze patrystycznej IV i poczatku $V$ wieku (w świetle pism kapadockich Ojców Kościoła i Jana Chryzostoma). Pracuje w Wydawnictwie Uniwersytetu Łódzkiego.

Zainteresowania naukowe: problematyka kobieca w okresie antyku oraz zagadnienia związane $\mathrm{z}$ dieta $\mathrm{w}$ pismach autorów wczesnochrześcijańskich.

(ㄱ.dybala@vp.pl

Prof. dr hab. Maciej Kokoszko - historyk i filolog klasyczny zatrudniony w Katedrze Historii Bizancjum Instytutu Historii, na Wydziale Filozoficzno-Historycznym Uniwersytetu Łódzkiego.

Zainteresowania naukowe: historia starożytna i dzieje Bizancjum, zwłaszcza historia wyżywienia i medycyny antycznej (szczególnie dorobek dietetyki i farmakologii do VII w. n.e.).

అ maciej.kokoszko@uni.lodz.pl; mkokoszko@komandor.pl 